\title{
INTEGRATING THEORY AND \\ PRACTICE INTO THE PROFESSIONAL RESPONSIBILITY CURRICULUM AT THE UNIVERSITY OF TEXAS
}

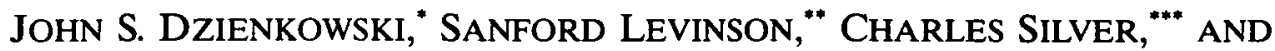 \\ AMON BURTON ${ }^{* * *}$
}

INTRODUCTION:

\section{The Keck Program at THE University of TeXas}

The University of Texas School of Law is a large law school with approximately 500 students in each class. ${ }^{1}$ Traditionally, students satisfy their professional responsibility requirement by taking a large lecture-style class of 80 to 160 students. In these large lecture classes, the students typically read an assignment from a traditional casebook and listen to a discussion between the professor and a necessarily small number of students about the courts' or the American Bar Association's ("ABA's") view of a particular problem. Although an introduction of the rules and the celebrated cases has its place in a course on ethics, the students in the large class are never forced to work through a particular ethical dilemma with one-on-one feedback over a number of classes. Nor, for example, are they asked to simulate an actual lawyering task raising professional responsibility issues, such as drafting a client consent to a conflict of interest. This produces a new, usually relatively young, lawyer who may be abstractly familiar with the topics in ethics, but who has never examined in depth, or with any sense of concreteness, the manner in which he or she should address a problem of professional responsibility.

Teaching ethics to the large class has always proved to be a great challenge for those of us who teach professional responsibility at Texas. The class is somewhat less satisfying than the other subjects that we teach even though most of us who teach ethics at Texas view the area as one of our primary interests. Many of us have tried different approaches to teaching the course to large

\footnotetext{
Copyright (C) 1996 by Law and Contemporary Problems

* Professor of Law and John Redditt Professor of State and Local Government, The University of Texas at Austin.

** W. St. John Garwood and W. St. John Garwood, Jr. Professor of Law, The University of Texas at Austin.

*** Cecil D. Redford Professor of Law, The University of Texas at Austin.

**** Adjunct Professor of Law, The University of Texas at Austin.

1. It is, with Harvard, NYU, George Washington, and Georgetown, among the very largest institutions of legal education in the country.
} 
classes, but without much success. ${ }^{2}$ Thus, when we received the invitation to apply for a grant from the W.M. Keck Foundation, we quickly sought to place our emphasis on how to better present the subject of professional responsibility to our students. In preparing the grant request, we sought to focus on how the University of Texas as a large law school could improve the manner in which professional responsibility is taught to the students. In light of this goal, the Keck Program at the University of Texas has three components to improve our professional responsibility curriculum. First, it includes a basic course in professional responsibility that integrates theory and practice into a large class format, which will remain the way that most students will confront the formal teaching of professional responsibility. Second, to increase the opportunity for students to address these issues in small classes as well, the program includes more specialized courses in professional responsibility, and, third, to allow intense focus, it includes a seminar on a particular aspect of legal practice.

Because we are currently in the second semester of year two of the Keck grant, ${ }^{3}$ our findings are based only upon a little over one year's experience in the program. Thus, in this essay, we will focus on the experience that we have had in the Keck Course offered to the larger class and in the Keck Seminar on the Large Law Firm Practice. ${ }^{4}$

2. One of us (Sanford Levinson) has tried to teach the large class out of a set of materials combining both theory (e.g., Plato's Gorgias) and a selected set of practical issues likely to arise in lawyering. Another one (Charles Silver) tried to offer students a basis for analyzing issues under both national and State of Texas standards by requiring students to study Robert Schuwerk and John Sutton's 1991 Commentary on the Texas Disciplinary Rules.

3. One of us (Charles Silver) is presently teaching a course on professional responsibility issues in litigation, and thus it is too early to present the findings on this offering. More than $\mathbf{4 0}$ students enrolled in the course, which focused on difficult and controversial questions of professional responsibility that arise in complex litigation. It is accurate to say that the course straddled the line between professional responsibility and advanced civil procedure. Professor Silver designed the course to follow the path a lawsuit might take from first contact with the legal system through pretrial and trial to settlement. He began with materials on attorney-client relationships, marketing legal services, and litigation finance, including the role of the marketplace, contingent fees, hourly rates, flat fees, and referral fees (in both conventional and group litigation). He then addressed interest conflicts, including attorney-client conflicts, concurrent-client conflicts, successive-client conflicts, conflicts generated by mobile attorneys, experts, and law firm employees, and issues particular to the representation of entity clients. The class then moved to the ethics of advocacy and to a long section on discovery abuse, including subchapters on the theory of discovery, apex depositions, coaching and paying witnesses, withholding information, handling of documents inappropriately obtained, and perjury. Finally, the class addressed settlement issues, including threatening civil, criminal, or disciplinary action to gain leverage in settlement negotiations, advising clients on settlement, and aggregate settlements involving multiple claims. The final week focused on ethical issues in insurance defense, an area of practice Professor Silver has studied and written about at great length. The readings employed in the class were interdisciplinary. Cases and related materials comprised about half the assignments, and there was significant emphasis on Texas law. The other half consisted of law review articles, economic analyses of legal behavior, philosophical readings, and lots of short articles taken from recent issues of legal periodicals (e.g., the ABA Journal) designed to inform the students that the issues being confronted are timely ones on the cutting edge of professional responsibility law.

4. We encourage faculty at other law schools to contact us for a sample of the type of materials we prepared for the Keck Course. At the end of the three-year grant, we plan to have a more fully developed set of materials for use in other law schools. 
II

\section{The Keck Course on TheORY AND PRactice In Professional RESPONSIBILITY}

\section{A. Designing the Keck Course: Goals, Course Content, and Assignments}

The major problem with teaching professional responsibility to students is the fact that they often do not appreciate the manner in which ethical problems arise in practice. Thus, they have difficulty in identifying the issues, in relating to how they arise, in researching problems in this area of the law, and in developing an analytical framework for resolving the problems. Thus, our goal for the Keck Course on Theory and Practice in Professional Responsibility was to develop a course that would help students identify ethical issues in the practice of law, research ethical problems, and develop an analytical framework for resolving ethical dilemmas.

From the beginning, we sought to bring together a member of the faculty and a practitioner who specialized in legal ethics in order to develop the course. Professor John Dzienkowski teamed with Adjunct Professor Amon Burton, ${ }^{5}$ who practices law in Austin and who had taught small courses in professional responsibility at the law school for several years. In the fall of 1994, Professors Dzienkowski and Burton taught the Keck Course to a group of fifty-five students through a variety of teaching methods. We began with a small group for two reasons. First, we wanted a group that was manageable enough to try different techniques on short notice without having to worry about monitoring whether all of the students had received the instructions. Second, we wanted the class to be small enough to give us personal feedback so that we could refine the course for future years. We planned to increase the size in years two and three of the Keck grant.

In offering a course co-taught by an academic and a practitioner, we made the decision early on that both teachers would participate and prepare for every session. Co-teaching by dividing up the topics would leave us with a course that could be done by inviting a series of guest lecturers to a normal class. Instead, we wanted to offer a course that was truly a collaborative effort to integrate theory and practice into the ethics course. To that end, Professors Dzienkowski and Burton met before each class and in many cases on the day before to prepare the manner in which they would teach the assigned subject area. They divided various roles between themselves and offered the students distinctly

5. Amon Burton practices in the fields of corporate, securities, and entertainment law, but in recent years has devoted more than half of his practice to legal ethics. He is a frequent expert witness and consultant on ethics matters in the State of Texas and around the country. Amon Burton is a member of the Texas Professional Ethics Committee that writes ethics opinions interpreting the Texas Disciplinary Rules, served as the Reporter for the Task Force on Judicial Ethics that drafted the revised Texas Code of Judicial Conduct, and is a member of the American Law Institute's Members Consultative Group on the Restatement of the Law: Law Governing Lawyers. 
different perspectives on the topic that was being presented. Coverage by lecture, group exercise or negotiation, videotape, or guest lecture varied to present the students with different perspectives on the problem and its resolution.

We made several fundamental decisions in the course. First, we required that the students learn the entire Model Rules of Professional Responsibility by the end of the first month of classes. ${ }^{6}$ At that time, we gave the students a multiple choice examination to test their knowledge of the Model Rules. The purpose for testing this material at the end of the first month was to ensure that we could spend the rest of the semester on a limited number of difficult ethics issues with the students already familiar with the relevant rules. Thus, we did not feel compelled to cover every topic covered by the rules after the examination. Further, we also felt that students should have a general awareness of the entire set of the rules even though we could not possibly discuss each rule in depth in class.

Second, we developed four different assignments, usually requiring that the students write a three- to five-page paper. The assignments were graded with comments and handed back to the students within a relatively short period of time. The first assignment gave the students a case study and asked them to analyze whether an attorney-client relationship existed. The second assignment asked the students to resolve a conflict of interest problem under both the Model Rules and the law of conflicts in the Fifth Circuit. The third assignment asked the students to examine the rule in Texas on referral fees and to provide a policy defense for or against the position taken in the rule. The fourth assignment required that the students examine and critique an actual attorneyclient fee agreement. The use of short, pointed, written assignments forced students to put themselves in a role not too different from that which they would occupy if faced with a similar role in practice. It gave them immediate feedback and often allowed us to explore the issues in far more depth in the classroom than if we had presented the topics through traditional readings.

Apart from the written assignments, at several points in the semester, we asked the students to prepare to discuss a particular issue. For example, we showed the students one of the University of Pennsylvania videotapes and assigned to groups of students different issues raised by the videotapes for a formal class presentation. ${ }^{7}$ Although the presentations were time consuming, we were impressed with the research skills of the students and the manner in which they presented the materials to the class through the group format. On another occasion, we asked the students to conduct a negotiation exercise in which they would need to address an ethical dilemma involving candor to the

6. We took the Model Rules and decided to cover the more difficult rules first so that the students would have a more informed view of the specific rules. With some of the material, we simply required that the students master the rules on their own. A review session was held in class with both a lecture on the nuances in some of the rules and a question and answer component.

7. We showed the tape entitled "The Morgantown Civic Center Collapse." 
opposing side. We discussed the results of the negotiation in class and the manner in which the law should regulate negotiation. Assignments geared to placing the students in the role of the lawyer faced with an ethical dilemma also sharpened the students appreciation for the ethical issue and forced them to react in a prompt manner.

For the final examination, we gave the students eight short answer questions and two long essay questions. The eight short answer questions were focused questions usually about a paragraph long, and the students were given about four pages to answer each question. The long essay questions were more akin to the traditional first-year examination question in which the issues are not apparent and the students must identify the issues and then attempt to resolve them through the reasoning learned in the course.

\section{B. Development of Innovative Materials}

One of the problems of teaching ethics to students is the difficulty of presenting ethical issues outside the context of a specific substantive area. Traditional casebook materials have not succeeded in presenting the ethical issues in a way that makes the problems real and comprehensible to the law student who often has no familiarity with the area of the substantive law or any sense of the stress and expectations inherent in the attorney-client relationship. Many of the participants in the Keck Program on Professional Responsibility have devoted time to developing materials for use in the classroom that address this concern. And, of course, this problem is directly addressed by those who offer professional responsibility through the pervasive method. We have attempted to address this problem by creating several case studies from actual problems that have arisen in the practice of law.

In choosing a problem for a case study, we sought to find a fact pattern that raises conflicting solutions driven by the law or the policy. For example, in one case study we produced, both the law and the policy presented lead to conflicting directions. We also sought to expose the students to different types of material. In some case studies, we used actual documents from the case, such as correspondence, excerpts from depositions, affidavits, and engagement letters. In others, we presented a narrative through the newspaper articles that appeared at the time of the conflict. We also sought to give the students the context of the law, by giving citations and notes presenting the surrounding literature or by reprinting a case that presents a similar or a contrasting position.

One case study that we produced for the Keck Course involves the Texas case of a baby sitter, Cathy Henderson, who disappeared with a three-month old baby. Ms. Henderson was apprehended in Missouri and assigned to a public defender. Her original position was that the baby died when he fell out of her hands accidentally and that she buried the baby in Texas and fled. At that time, the public defender asked the authorities for a map of Texas, and this led to the ethical problem. Ms. Henderson drew a map of where the baby's body was located; however, she was extradited to Texas, but the map remained in 
Missouri. The public defender faxed and later sent the original of the map to Ms. Henderson's new Texas counsel, Nona Byington. Ms. Byington became the target of harassment, searches, and eventually a proceeding to obtain the map. We present the case through the use of newspaper articles that came out around the time of the dispute.

This case study accomplishes many goals. First, it presents the classic problem of zealous advocacy and the extent to which a lawyer can protect information given by the client. Second, the case unfolds through a narrative provided by articles written at a time when no judicial decision had been made, which allows us to spend time exploring how the students would have handled the case. ${ }^{8}$ Third, it evokes significant emotion on the side of the parents who would like to recover the baby's body, which raises a moral dilemma for the attorney and nicely highlights the conflict between decisions driven by role morality versus personal morality. Fourth, it raises the issues of how to define confidential information and the continuing crime exception. (Of course, students are tempted to find some exception to permit disclosure.) Finally, the resolution of the case in real life through an examination of the attorney-client privilege gives the students a surprise ending. The judge relies upon the cases that find no attorney-client privilege attaches when a client gives information to the lawyer that is not intended to be confidential. This result shows the students that ethical issues must be studied not just from the perspective of ABA and state ethics codes. Sources of professional responsibility include rules of evidence, procedure, and many other areas that form the law of lawyering.

\section{The Use of Keck Lecturers and Speakers}

Over the years, most professional responsibility teachers have used guest speakers to help bring theory and practice into their classes. Such lectures have been delivered by other professors, judges, practitioners, and representatives from the state bar. A carefully planned guest lecture often provides an excellent manner of exposing students to material that otherwise would be difficult to present in the typical classroom context. There is something about having an author of an article or book or a lawyer who argued a particular case come into the classroom and present his or her ideas before a group of wellprepared students that cannot be replicated by the text of the work or opinion alone. In the Keck Course, we tried to offer some depth to the involvement of a guest speaker.

Professors Dzienkowski and Burton asked Steve McConnico, a partner at the law firm of Scott, Douglass, Luton \& McConnico, who specializes in malpractice defense, to become the Keck Lecturer in Ethics and participate in the course for the equivalent of a two-week period to focus on the area of mal-

8. We always ask the students how they would have handled the situation if they had found the map on the fax machine after returning from lunch. The responses give us much material for discussion. 
practice and the failed financial institution litigation that had taken place in Texas. ${ }^{9}$ During the first part of this two-week session, Steve McConnico presented materials on the law of malpractice. He focused on theories of malpractice litigation and unresolved cutting edge issues in the states. Then the students received actual, but sanitized, documents from an FDIC case against a law firm. They were asked to study the documents, including the expert opinion letters. Steve McConnico and one of his partners, Sam Johnson, respectively took the plaintiff and defense position in the case and gave opening arguments to a jury for this fact pattern. The students asked questions of each side just as if an appellate court would ask questions of the attorneys for each party. McConnico and his partner then described how the case unfolded from both a practical and legal perspective. The students were asked to focus on how the law firm could have avoided the actions or inactions that led to the charges of malpractice. The final sessions with. Steve McConnico focused on the Kaye Scholer case and the developments in the law directed toward attorneys that were implemented to prevent another wave of failed financial institutions.

The use of a seasoned practitioner to present two weeks of material in a concentrated area of the law proved very beneficial. The students received a perspective on the general area of malpractice litigation and the specific problem of lawyer involvement in bank failures that could not be replicated through the use of casebook materials. Essentially, they had a chance to walk through a case without having to devote the time to an entire trial. The use of an extended visitor with proper focus and the creation of a set of materials significantly enhanced the classroom experience.

\section{The Future}

Professors John Dzienkowski and Amon Burton offered the Keck course a second time to the students in the Spring of 1996 and refined the course and produced another case study. We hope to somehow institutionalize the concept of co-teaching the ethics courses with a regular member of the faculty and a member of the bar.

9. See John S. Dzienkowski, An Introduction to the Symposium: The Impact of Failed Fiancial Institution Litigation in the Regulation of Lawyers, 12 REV. LIT. 513 (1993) 


\section{III}

\section{InVolving Students IN THE Disciplinary PRocess of the State BaR OF TEXAS}

\section{A. Designing a Cooperative Venture Between a Law School and the State Bar}

All of the publicity surrounding the Keck Program at the University of Texas and the involvement of the teachers of professional responsibility with state ethics issues contributed to the invitation that James McCormack, the General Counsel of the State Bar of Texas, made to the law school. In the Spring of 1995, Mr. McCormack contacted several of the professional responsibility professors working on the Keck Program and invited us to develop a joint program between the State Bar and the law school involving the State Bar Association's effort to enforce Texas disciplinary law.

The major problem presented by the cooperative venture involved the practical problem of including a large number of students in a professional responsibility experience for a short period of time in a meaningful way. In the past, professors at the law school had referred students to the State Bar for internships and the State Bar had hired a small number of students for employment. Students had even been included on some bar committees. ${ }^{10}$ However, we sought to expose far larger numbers of students to the process by which the State Bar implements the rules of ethics.

The State Bar of Texas operates one of the most aggressive and successful grievance procedures of any bar association in the country. Thus, a logical beginning for a cooperative venture was to include students in the disciplinary process. Throughout the Spring of 1995, James McCormack, Professors Burton, Dzienkowski, and Charles Silver met in an effort to design a workable model for student involvement in the lawyer discipline process. Threshold issues included the need to preserve the confidentiality of the State Bar deliberations in individual hearings and the need to build a strong academic component into the program. The model developed makes law students interns of the State Bar of Texas for one series of confidential grievance panel hearings where complaints against lawyers are aired.

The lawyer disciplinary system in Texas is based upon district grievance committees. Each grievance committee consists of at least nine members, of which two-thirds are lawyers and one-third are citizens who are not licensed lawyers. The members are appointed by the President of the State Bar of Texas. These committees make the initial determination whether "just cause" exists to conclude that the lawyer has engaged in professional misconduct by violating a provision of the Texas Disciplinary Rules of Professional Conduct.

10. The State Bar had included students as members of the Character and Fitness Committee. 
The proceedings are initiated by a complaint filed with the State Bar, and all grievance committee hearings are confidential. ${ }^{11}$ If the grievance committee, or panel of committee members designated to hear the complaint, finds misconduct by a majority vote, they present the lawyer with a recommended sanction. If the lawyer refuses to accept the sanction, the lawyer's options are to request an administrative evidentiary hearing or a trial de novo in a district court.

Once we decided to implement the hearing internship model, we thought that we should test the program before actually adopting it in a classroom. Both the law school and the State Bar needed to determine whether the hearing internship model could work for an entire class of students.

We decided to use research assistants in an experimental test of the program. Five research assistants, employed by Professor Silver, served as "guinea pigs." They met Mr. McCormack and other representatives of the General Counsel's office, received materials describing the disciplinary process, signed confidentiality statements, read files containing information about pending complaints, attended panel hearings at which the complaints were aired, and submitted memoranda describing their experiences and suggesting ways the process could be improved. Professor Silver distributed the student memoranda to everyone involved in the planning process and personally interviewed the research assistants about their experiences and suggestions. Even with all of our encouragement to the research assistants for a critical review, they reported that it was a positive experience that should be expanded to all students in the law school. ${ }^{12}$ We held a subsequent planning session and fine-tuned the process for implementation.

We strongly suggest that any cooperative venture between the organized bar and a law school be tested through a controlled experiment such as the one we tried before implementing the disciplinary hearing internship. The involvement of students on a limited basis served several functions aside from fine-tuning the process. Given the need for total cooperation from the various individuals involved in the State Bar disciplinary process, a trial run builds confidence with individual disciplinary panel members. It also gives the leadership within the bar an experience to point to when trying to convince others that the program is a positive experience. Further, it allows the development of internal bar procedures to handle the number of students that will participate in the program when it is offered on a course-wide basis.

11. Thus, students must sign confidentiality agreements, and we make a violation subject to the law school's disciplinary honor code. Lawyers are also give the opportunity to object to the students' participation.

12. This was a surprising conclusion to us because most of the student research assistants thought that the involvement in the disciplinary hearing would be a waste of time. 


\section{B. Our First-Year Experience}

Professor Amon Burton was the first person to adopt the State Bar Internship program at the University of Texas School of Law. In a class of eighty students during the summer of 1995, Professor Burton offered the class the option of participating in the program. Participation was made optional because we were not certain if the State Bar could handle all of the students during a four-week summer term. Surprisingly, sixty-five students showed an interest in attending the disciplinary hearings. It quickly became obvious that not all of the interested students could be accommodated; hence a lottery system determined which students could fill the twenty-four intern slots available in Austin. The other students were offered the opportunity to attend grievance hearings in other cities if their summer plans permitted and if arrangements could be worked out with local grievance committees. ${ }^{13}$

The participating student interns read the grievance files before the day's hearing, sat in all grievance proceedings heard by the committee on that particular day, and listened to panel deliberations of whether the lawyer's conduct constituted misconduct. Each student was also required to submit a confidential six- to ten-page critique of the experience. ${ }^{14}$ The critiques included an analysis of the alleged disciplinary violation and relevant facts, what factors the student thought were relevant to the decision reached by the grievance panel, and what the students had learned from the experience. All of the participating students thought that attending a grievance proceeding was a useful learning experience. One typical student response follows:

The exposure [to a disciplinary proceeding] makes a lasting impression on potential lawyers. To see an experienced lawyer try to convince his peers not to take away his license which represents his livelihood and much of his self-worth and self-image is striking. My first reaction upon leaving the hearing was: "I am going to make damn sure that $I$ never put myself in a position where $I$ wind up in front of a similar committee." The exposure has deterrent value.

Professor Burton also required the entire class to attend an evidentiary hearing held in the Jeffers Courtroom at the University of Texas School of Law. The evidentiary hearing is an administrative appellate proceeding held when an attorney does not consent to sanctions imposed by a grievance panel. The evidentiary panel makes findings of fact and law, and its decision can be appealed only to the Texas Supreme Court. In the hearing that Professor Burton's class attended, the attorney, who was currently serving probation from a prior disciplinary violation, had stipulated that she lied to a court about whether discovery requests had been conveyed to her client, but a clinical psychologist testified on behalf of the attorney that she was now developing new patterns for dealing with difficult clients and stressful situations. The panel

13. Several students attended grievance hearings in other cities in the state.

14. The student paper did not include any identifying information about the target of the State Bar inquiry, and facts were sufficiently generalized so as to protect the confidentiality of the process. 
suspended the lawyer from practicing law for one year and then required a three-year period of probation. Student comments following the hearing primarily focused on how the evidence indicated that her problems in dealing with clients were a reflection of her personal psychological problems. In class, this led to a discussion of how lawyers deal with stress and how lawyers relate to clients. These difficult topics, which students usually hear about in the abstract, became very real and focused on the problems of this particular attorney.

Because the grievance panel hearings are confidential, we decided to limit the number of students attending the panels to three. ${ }^{15}$ We also placed significant restrictions on the students' ability to discuss facts relating to particular grievances in their memoranda. Finally, in response to concerns expressed by the members of the committees, we decided to allow the lawyers the right to exclude student interns. The evidentiary hearings pose no such problem; however, there are relatively few evidentiary hearings during a typical semester in the Austin area.

\section{The Future}

We are very pleased with the results of the cooperative venture between the State Bar of Texas and the University of Texas School of Law. The student response has been very positive. The lawyer grievance program is a true, unique, and important improvement in the professional responsibility curriculum. The program does a far better job of bringing professional responsibility issues to life for our students than a series of lectures about the grievance process possibly could. The sight of a lawyer defending a complaint filed by an aggrieved client in front of a panel of lawyers and laypersons is a stirring one for the students, even when the complaint turns out to be unfounded. We hope to move all grievance panels and evidentiary hearings into the University of Texas School of Law when our courtroom facility is complete. That will make the disciplinary process a fixture in the students' lives and will make it easier for them to observe the proceedings.

The State Bar internship program clearly has implications beyond the learning experience for the students. The program has created a cooperative atmosphere between the law school and the State Bar, and both sides have benefitted from the relationship. It is apparent from the student critiques that this program can collect valuable information about the functioning of the decisionmaking process of the grievance committees. This information should form the beginning of a data collection process that will allow the State Bar to evaluate the strengths and weaknesses of the grievance system. After a full year of student participation, we plan to examine the student reports and prepare a written report about this experimental program. We believe this program has

15. In some instances, we have reduced this number to two students because of the concern of the members of the committee that three students posed a threat to the operation of the committee. 
clear benefits to the bar and the academy and will contribute to learning more about the regulation of lawyers in the state.

The important goal for the future is to institutionalize the ethics internship program so that it can continue into the foreseeable future. We hope to continue the program at the University of Texas, which will require a commitment from the institution for the administrative effort in managing such a program. We hope that the program can be firmly institutionalized so that it will continue with the State Bar's full support on a state-wide basis. We also hope that we can help other schools around the state of Texas implement the internship program. Although the program requires significant coordination and a commitment of resources on behalf of the school and the State Bar ${ }^{16}$ we believe that the glimpse offered to students in this model cannot be replicated in another manner. Students gain a sense of appreciation of the ethics rules in actions where the consequences of a violation are real and often severe for the lawyer involved in the process. This heightens the students' sense of the importance of the course and gives them an experience not shared by many other lawyers. We hope student interns will become involved in the State Bar process when they become members of the bar and, in light of their experience, help reform the manner in which lawyers are regulated.

IV

\section{The Keck Seminar on Advanced Ethics Problems}

Although the University of Texas has offered seminars in professional responsibility on a sporadic basis, we have rarely focused such seminars on advanced problems in professional responsibility. The seminars offered in the past have focused on selected issues and have simply consisted of the traditional seminar paper-writing process with extensive discussion. In 1994, however, even before the University of Texas applied for the Keck Grant, Professors Sanford Levinson and Elizabeth Chambliss collaborated with Gibson Gayle, the former managing partner of Fulbright \& Jaworski-one of the nation's largest law firms, based in Houston, in an experimental seminar on the various issues surrounding the specific phenomenon of what Marc Galanter has termed the "mega firm." Gayle was able to bring to the seminar an extraordinary group of managing partners, administrative partners, and general counsel of major firms and companies. Their presentations were candid and challenging, especially when coupled with the assignment of more traditional academic materials. We were also able to bring in Professor Robert Gordon, then at Stanford. We judged the experiment to be a great success, not least because of

16. At this time, the major problem with the program is the difficulty of placing more than 40 students per semester into grievance panels. We have examined other ways in which students could be involved in the State Bar discipline process and may consider experimenting with some of those alternatives in the future. This would potentially double the number of students that could participate in this real life experience. 
the commitment, energy, and insight of Gayle. Thus we seized the opportunity provided by the Keck grant to continue the experiment in 1995.

Thus, in the Spring of 1995, Professor Levinson, with help from Professor Chambliss, directed the Keck Seminar on the Large Law Firm Practice. ${ }^{17}$ The seminar began with a survey of some of the academic literature on the contemporary large law firm, including the extremely influential analysis of Marc Galanter and Thomas Paley, "The Tournament of Lawyers." We were privileged to have Professor Galanter join the seminar for a session, where he both replied to various criticisms leveled at his argument and described some more recent work he is doing on law-firm development in London. Surely one reason for the intense student interest in these issues is that most of them are in fact intending to work for large law firms, a fact both advantageous and disadvantageous to the overall seminar. Students yearn for information about the legal setting they have chosen, often with surprisingly little knowledge. On the other hand, they are sometimes a bit impatient with the more purely academic interests of Professors Levinson and Chambliss, both of whom have Ph.D.s in social science and are fascinated by many of the theoretical problems raised by the phenomenon of the large law firm.

Along with Professor Galanter, two other distinguished academics came to Austin to meet with the seminar. Professor David Wilkins came from Harvard to report on research he is doing regarding the integration of racial minorities into large law firm practice. He also delivered the first Keck Lecture on the ethical issues surrounding the representation by an African-American attorney of the Ku Klux Klan in a civil liberties matter. ${ }^{18}$ Professor Wilkins addressed whether the African-American attorney owed "special duties" to the AfricanAmerican community with regard either to client selection or the positions that the attorney would be willing to argue. Finally, Professor Gordon returned to discuss both his classic article on the "civic-republican" conception of lawyering and a new article on progress on the background assumptions of any functioning legal order and their implications for conceptions of adversarial zeal and single-minded devotion to the client's interest.

Although, as noted, Gibson Gayle was unable to be present for the seminar, he continued to exert himself to make sure that we were once again visited by extremely knowledgeable leaders of the large-firm segment of the Texas Bar. In particular, the students benefitted from appearances by William Barnett, the managing partner of Baker \& Botts in Houston, Kenneth Roberts, the former general counsel of EXXON, now of counsel at Fulbright \& Jaworski, Jack Vaughn and James R. Willis, the administrative partner and director of administration, respectively, of Fulbright \& Jaworski and Baker \& Botts, and

17. Gayle unfortunately became ill and was confined to Houston for the spring. He has, however, recovered and is in fact participating in the Spring 1996 seminar.

18. Ex parte Lowe, 887 S.W.2d 1 (Tex. 1994) 
Piet Schenkkan, the former managing partner of the Austin branch of Vinson \& Elkins.

In addition to this plethora of appearances by outside practitioners and scholars, Professor Chambliss presented material she has been writing on the role of women and minorities in large law firms, and Professor Dzienkowski addressed the issue of positional conflicts, a subject of ever-increasing interest, both theoretically and practically, in the setting of large law firm practice. ${ }^{19}$ Professor Levinson also presented a session focusing on the particular tensions that can arise between a young associate, perhaps imbued with the norms of professional responsibility as taught at law school, and a supervising partner who makes arguably questionable demands.

Again, although the students missed Gayle, the Keck Seminar on the Large Law Firm Practice was a great success. Professors Levinson and Chambliss integrated the various speakers into a theoretical and practical look at large law firm practice. This web of theory and practice gave the students an excellent background for writing seminar papers. Professor Chambliss offered a Keck Seminar on the Large Law Firm Practice with a slightly different focus in the Spring of 1996. We also hope to develop several other seminars in advanced professional responsibility issues before the end of the grant term.

\section{$\mathrm{V}$ \\ CONCLUSION}

We believe that after the first year of the Keck Program at the University of Texas, we have made significant advances in the teaching of professional responsibility at our institution. The materials we are developing in the Keck Course on Theory and Practice have been used in other ethics course at the school and will be available for distribution at the end of the grant. The Keck Seminar on the Large Law Firm Practice has give us exposure to both leading academics and practitioners in this field, which will have an influence on the manner in which we teach and write in professional responsibility. Finally, we believe that our cooperative venture with the State Bar of Texas will become a very important component in exposing students to the real life situations involving ethics problems. This is the most significant new development in the teaching of professional responsibility at the University of Texis, and we hope to expand its influence in the future. 